\title{
ANTIBODY FORMATION IN CASES OF LOBAR PNEUMONIA TREATED WITH SULFATHIAZOLE
}

\author{
By YALE KNEELAND, JR., AND BARBARA MULLIKEN \\ (From the Department of Medicine, College of Physicians and Surgeons, Columbia University, \\ and the Presbyterian Hospital, New York City)
}

(Received for publication June 14, 1940)

Early in 1940 we published a report (1) on antibody formation in cases of lobar pneumonia treated with sulfapyridine. In nineteen treated cases of pneumococcus pneumonia repeatedly studied during the acute phase of the disease and during convalescence, an excess of type-specific antibody was only demonstrated in the serum of four. In the past it has often been shown that spontaneous recovery from lobar pneumonia is associated, in the great majority of instances, with the appearance of an excess of antibody in the patient's serum, and this phenomenon has been generally regarded as an essential part of the mechanism of spontaneously occurring crisis. Our failure to demonstrate antibodies in fifteen out of nineteen cases suggested to us that sulfapyridine had supplanted, at least to some degree, this portion of the immune process. We did not believe that antibody-production ceased to exist in treated cases, but rather that it proceeded at a lower rate, probably because the stimulus to antibody formation was lessened as a result of the action of the drug on the invading organism. Our technique for the demonstration of excess antibody throughout the series studied was the precipitin reaction with type-specific polysaccharide.

While this paper was in press, two similar studies were published. Wood and Long (2) reported the appearance of mouse-protective antibodies in the serum of ten out of eleven treated patients recovering from lobar pneumonia but pointed out that in seven of these cases antibody appeared after the time of " essential recovery." Subsequently, Finland and his associates (3) reported a large series of cases of pneumococcus pneumonia in which mouse-protective antibodies and agglutinins were sought. They concluded as a result of these studies that "the antibody response of patients with pneumococcic pneumonia treated with sulfapyridine, as far as could be determined, was comparable in every respect to that resulting from spontaneous recovery." It will be observed that these results were not in accord with our findings. None of these investigators, however, used the same technique as we did-to wit, the precipitin reaction. It is our belief that the precipitin reaction, as Heidelberger and Kendall (4) have pointed out, is probably less sensitive than the other methods, but that it is more clear-cut and more specific. Unfortunately, at the time our paper was written, we had no control series of our own in which untreated patients were studied by the same technique, although such was present in the literature (5). As will be observed, the results which we obtained in patients treated with sulfathiazole, as opposed to sulfapyridine, using precisely the same technique, were almost diametrically different, and therefore constitute a very satisfactory control of the method.

Before sulfathiazole was introduced, eleven additional sulfapyridine-treated cases were studied in the same manner as those reported in the original paper. Including one doubtful reaction, only four of these showed precipitins during convalescence. Adding these to the original series, we have then a total of thirty cases of pneumococcus pneumonia treated with sulfapyridine; of these twenty-two, or nearly seventy-five per cent, recovered from the disease without the appearance of an excess of antibody in the blood serum as demonstrated by the precipitin reaction.

The chief purpose of the present communication is to describe the results which we obtained when an exactly similar study was made of patients treated with sulfathiazole.

\section{MATERIALS AND METHODS}

These were precisely the same as those employed in the preceding paper (1), and will not be described in detail. The precipitin reaction 
with type-specific polysaccharide was employed throughout.

\section{RESULTS}

The accompanying table gives our data on twenty-one cases of lobar pneumonia treated with sulfathiazole which were investigated serologically for the appearance of type-specific antibodies by means of the precipitin reaction with specific polysaccharide. Altogether ten different types of pneumococcus pneumonia are represented. It will be observed that circulating antibody was detected by this means in sixteen out of the twenty-one cases. Of the five which failed to show antibody, two were type $i$, and three types iv, v, and xiv, respectively.

The time of appearance of the antibody is of considerable interest. Of thirteen cases in which

TABLE I

Type specific antibodies investigated in twenty-one cases of sulfathiazole-treated preumonia

\begin{tabular}{|c|c|c|c|c|c|c|c|c|c|c|c|c|c|}
\hline$\underset{\text { ber }}{\text { Case }}$ & Sex & Age & $\begin{array}{l}\text { Dura- } \\
\text { tion } \\
\text { of } \\
\text { disease } \\
\text { before } \\
\text { treat- } \\
\text { ment }\end{array}$ & Type & Lobe & $\begin{array}{l}\text { White } \\
\text { blood } \\
\text { cells }\end{array}$ & $\begin{array}{l}\text { Tem- } \\
\text { pera- } \\
\text { ture } \\
\text { be- } \\
\text { fore } \\
\text { treat- } \\
\text { ment }\end{array}$ & $\begin{array}{l}\text { Date } \\
\text { treatment } \\
\text { started }\end{array}$ & $\begin{array}{c}\text { Date } \\
\text { temperature } \\
\text { normal }\end{array}$ & *Precipitin & ests & $\begin{array}{l}\text { Total } \\
\text { dose } \\
\text { sul- } \\
\text { fathi- } \\
\text { azole }\end{array}$ & Remarks \\
\hline 1 & $\mathbf{M}$ & 57 & 1 day & ii & LLL & $\begin{array}{l}\mathbf{3 5 , 2 0 0} \\
\mathbf{P .} \mathbf{9 2 \%}\end{array}$ & 104.8 & December 4 & December 5 & $\begin{array}{l}\text { December } 6 \\
\text { December } 8 \\
\text { December } 9 \\
\text { December } 11 \\
\text { December 13 } \\
\text { December 15 } \\
\text { December 16 } \\
\text { December 18 } \\
\text { December 20 } \\
\text { December } 23\end{array}$ & $\begin{array}{l}00 \\
00 \\
00 \\
00 \\
+0 \\
++ \\
++ \\
0+ \\
++ \\
++\end{array}$ & $\begin{array}{l}\text { grams } \\
26\end{array}$ & - \\
\hline 2 & $\mathbf{M}$ & 21 & 1 day & zaii & RLL & $\begin{array}{l}36,800 \\
\text { P. } 91 \%\end{array}$ & 106.4 & January 24 & January 25 & $\begin{array}{|lr|}\text { January } & 26 \\
\text { January } & 29 \\
\text { January } & 30 \\
\text { January } & 31 \\
\text { February } & 3\end{array}$ & $\begin{array}{l}\mathbf{0 0} \\
\mathbf{0 0} \\
\mathbf{0 0} \\
+t \\
+t\end{array}$ & 27 & \\
\hline 3 & $\mathbf{M}$ & 25 & 1 day & $\mathbf{i}$ & LLL & $\begin{array}{l}17,090 \\
\text { P. } 83 \%\end{array}$ & 103 & February 6 & February 8 & \begin{tabular}{|lr} 
February 9 \\
February 12 \\
February 14
\end{tabular} & $\begin{array}{l}\mathbf{0 0} \\
\mathbf{0 0} \\
\mathbf{0 0}\end{array}$ & 31 & \\
\hline 4 & $\mathbf{F}$ & 42 & 1 day & iii & $\begin{array}{l}\text { RML } \\
\text { RLL }\end{array}$ & $\begin{array}{l}10,700 \\
\text { P. } 92 \%\end{array}$ & 104.4 & February 10 & February 13 & February 20 & $+t$ & 66.5 & $\begin{array}{l}\text { Developed a sterile pleurisy } \\
\text { during resolution. Drug } \\
\text { fever on twelfth day of } \\
\text { treatment. }\end{array}$ \\
\hline 5 & $\mathbf{M}$ & 24 & 1 day & $\mathbf{v}$ & RUL & $\begin{array}{l}17,560 \\
\text { P. } 97 \%\end{array}$ & 103.8 & February 11 & February 19 & \begin{tabular}{|l} 
February 13 \\
February 16 \\
February 19 \\
February 21 \\
February 23 \\
February 26
\end{tabular} & $\begin{array}{l}\mathbf{0 0} \\
00 \\
00 \\
00 \\
00 \\
00\end{array}$ & 74.5 & $\begin{array}{l}\text { Temperature normal on } \\
\text { February 13, but rose the } \\
\text { next day. Dosage in- } \\
\text { creased to } 12 \text { grams a } \\
\text { day, with eventual good } \\
\text { result. }\end{array}$ \\
\hline 6 & F & 58 & 3 days & vii & LLL & $\begin{array}{r}22,000 \\
\text { P. } 80 \%\end{array}$ & 103 & March 4 & March 6 & $\begin{array}{lr}\text { March } & 6 \\
\text { March } 8 \\
\text { March } 11 \\
\text { March } 13 \\
\text { March } 15 \\
\text { March } 18 \\
\text { March } 20 \\
\text { March } 25 \\
\text { March } 26\end{array}$ & $\begin{array}{l}00 \\
00 \\
00 \\
++ \\
++ \\
++ \\
++ \\
00 \\
00\end{array}$ & 34 & $\begin{array}{l}\text { Hypertensive cardiovascu- } \\
\text { lar disease. Auricular fi- } \\
\text { brillation. Some conges- } \\
\text { tive failure. Drug fever } \\
\text { on the tenth day of treat- } \\
\text { ment. }\end{array}$ \\
\hline 7 & $\mathbf{F}$ & 68 & 1 day & moriii & $\begin{array}{c}\text { Central } \\
\text { right } \\
\text { mid } \\
\text { lung }\end{array}$ & $\begin{array}{l}16,500 \\
\text { P. } 81 \%\end{array}$ & 104 & March 6 & March 7 & $\begin{array}{l}\text { March } 13 \\
\text { March } 15 \\
\text { March } 18\end{array}$ & $\begin{array}{l}\mathbf{0 0} \\
++\end{array}$ & 30 & \\
\hline 8 & $\mathbf{M}$ & 75 & 3 days & iii & RLL & $\begin{array}{l}16,000 \\
\text { P. } 90 \%\end{array}$ & 104 & March 17 & March 23 & $\begin{array}{l}\text { March } 22 \\
\text { March } 25 \\
\text { March } 29\end{array}$ & $\begin{array}{l}00 \\
0+ \\
++\end{array}$ & 42 & \\
\hline 9 & $\mathbf{F}$ & 57 & 1 day & iii & $\begin{array}{l}\text { RUL } \\
\text { RML }\end{array}$ & $\begin{array}{c}23,600 \\
\text { P. } 90 \%\end{array}$ & 104 & March 17 & March 24 & March 25 & $+t$ & 60 & \\
\hline 10 & F & 51 & 3 days & vii & RUL & $\begin{array}{r}22.080 \\
\text { P. } 87 \%\end{array}$ & 105 & March 19 & March 21 & $\begin{array}{rr}\text { March } 19 \\
\text { March } 23 \\
\text { March } 26 \\
\text { March } 29 \\
\text { April } 1 \\
\text { April } \\
\text { April } 5 \\
\text { April } 8 \\
\text { April } 11\end{array}$ & $\begin{array}{l}\mathbf{0 0} \\
\mathbf{0 0} \\
\mathbf{0 0} \\
\mathbf{0 0} \\
\mathbf{0 0} \\
\mathbf{0 0} \\
\mathbf{0 0} \\
\mathbf{0 0} \\
++\end{array}$ & 35 & $\begin{array}{l}\text { Apparently had drug fever } \\
\text { from March } 22 \text { to March } \\
\text { 26. }\end{array}$ \\
\hline
\end{tabular}


TABLE I-Continued

\begin{tabular}{|c|c|c|c|c|c|c|c|c|c|c|c|c|}
\hline$\underset{\text { ber }}{\text { Case }}$ & $\operatorname{Sex} \mid$ & Age & $\begin{array}{c}\text { Dura- } \\
\text { tion } \\
\text { of } \\
\text { disease } \\
\text { before } \\
\text { treat- } \\
\text { ment }\end{array}$ & Type & Lobe & $\begin{array}{l}\text { White } \\
\text { blood } \\
\text { cells }\end{array}$ & $\begin{array}{l}\text { Tem- } \\
\text { pera- } \\
\text { ture } \\
\text { be- } \\
\text { fore } \\
\text { treat- } \\
\text { ment }\end{array}$ & $\begin{array}{l}\text { Date } \\
\text { treatment } \\
\text { started }\end{array}$ & $\begin{array}{c}\text { Date } \\
\text { temperature } \\
\text { normal }\end{array}$ & *Precipitin tests & $\begin{array}{l}\text { Total } \\
\text { dose } \\
\text { sul- } \\
\text { fathi- } \\
\text { azole }\end{array}$ & Remarks \\
\hline 11 & $\mathbf{F}$ & 23 & 36 hours & $\mathbf{i}$ & LLL & $\begin{array}{c}20,720 \\
\text { P. } 81 \%\end{array}$ & 105 & March 21 & March 23 & $\begin{array}{cc}\text { March 23 } & 00 \\
\text { March 25 } & ++ \\
\text { March 27 } & ++ \\
\text { March 29 } & ++ \\
\text { April 3 } & ++ \\
\text { April } 5 & ++ \\
\text { April } & +\end{array}$ & $\begin{array}{c}\text { grams } \\
41\end{array}$ & $\begin{array}{l}\text { Severe diabetic. Type zx } \\
\text { pneumonia in 1935. Type } \\
\text { ziv pneumonia in Feb- } \\
\text { ruary } 1940 \text {. }\end{array}$ \\
\hline 12 & $\mathbf{M}$ & 17 & 12 hours & vii & LLL & $\begin{array}{c}18,000 \\
\text { P. } 92 \%\end{array}$ & 103.6 & March 26 & March 28 & $\begin{array}{lcc}\text { April } & 2 & 00 \\
\text { April } & 3 & 00 \\
\text { April } & 5 & ++\end{array}$ & 23 & \\
\hline 13 & $\mathbf{M}$ & 55 & 4 days & vii & LLL & $\begin{array}{l}21,320 \\
\text { P. } 88 \%\end{array}$ & 105 & April 1 & April 2 & $\begin{array}{lll}\text { April } & 2 & 0+ \\
\text { April } & 5 & ++ \\
\text { April } & \mathbf{8} & ++ \\
\text { April } & \mathbf{+} & \mathbf{0 0}\end{array}$ & 45 & \\
\hline 14 & $\mathbf{M}$ & 25 & 36 hours & $v$ & RLL & $\begin{array}{l}27,600 \\
\text { P. } 94 \%\end{array}$ & 105 & April 7 & $?$ & $\begin{array}{ll}\text { April 12 } & 00 \\
\text { April 15 } & 00 \\
\text { April 17 } & ++ \\
\text { April 20 } & ++ \\
\text { April 22 } & 0+ \\
\text { April 24 } & \text { 00 }\end{array}$ & 74 & $\begin{array}{l}\text { It is uncertain when "es- } \\
\text { sential recovery" took } \\
\text { place here; fever re- } \\
\text { mained between } 101^{\circ} \text { and } \\
102^{\circ} \text { until April } 14 \text {, when } \\
\text { it rose, reaching } 104^{\circ} \text { on } \\
\text { April 16. Drug was } \\
\text { stopped, and temperature } \\
\text { promptly fell. Patient } \\
\text { also had sterile effusion. }\end{array}$ \\
\hline 15 & F & 53 & 2 days & xiv & LLL & $\begin{array}{l}21,280 \\
\text { P. } 86 \%\end{array}$ & 105 & April 23 & April 27 & $\begin{array}{lll}\text { May } & 2 & 00 \\
\text { May } & 4 & 00 \\
\text { May } & 6 & 00 \\
\text { May } & 8 & 00\end{array}$ & 62 & $\begin{array}{l}\text { Rheumatic heart disease, } \\
\text { auricular fibrillation, hy- } \\
\text { pertension, diabetes mel- } \\
\text { litus. Had drug fever } \\
\text { and rash on May } 2 \text {. }\end{array}$ \\
\hline 16 & $\mathbf{M}$ & 31 & 3 days & $\mathbf{i}$ & LLL & $\begin{array}{c}23,680 \\
\text { P. } 96 \%\end{array}$ & 104 & April 27 & April 30 & $\begin{array}{lrl}\text { April } & 30 & 00 \\
\text { May } & 3 & ++ \\
\text { May } & 6 & ++ \\
\end{array}$ & 43 & $\begin{array}{l}\text { Had } 6 \text { grams of sulfapyri- } \\
\text { dine before starting on } \\
\text { sulfathiazole. }\end{array}$ \\
\hline 17 & $\mathbf{F}$ & 63 & 5 days & iv & RLL & $\begin{array}{l}27,840 \\
\text { P. } 85 \%\end{array}$ & 104 & May 2 & May 4 & $\begin{array}{lrl}\text { May } & 4 & 00 \\
\text { May } & 6 & 00 \\
\text { May } 8 & 00 \\
\text { May } 10 & 00 \\
\end{array}$ & & $\begin{array}{l}\text { History of syphilis, partly } \\
\text { positive serology, arterio- } \\
\text { sclerotic heart disease. }\end{array}$ \\
\hline 18 & $\mathbf{M}$ & 23 & 3 days & i & RLL & $\begin{array}{l}29,920 \\
\text { P. } 94 \%\end{array}$ & 105 & May 3 & May 4 & $\begin{array}{lrr}\text { May } & 6 & 00 \\
\text { May } 8 & 00 \\
\text { May } 10 & 00 \\
\end{array}$ & 27 & \\
\hline 19 & $\mathbf{M}$ & 32 & 5 days & viii & RLL & $\begin{array}{r}32,680 \\
\text { P. } 90 \%\end{array}$ & 104.2 & May 6 & May 11 & $\begin{array}{lll}\text { May } 7 & 00 \\
\text { May } 10 & ++ \\
\text { May } 15 & ++ \\
\end{array}$ & 51 & $\begin{array}{l}\text { Had } 7 \text { grams of sulfapyri- } \\
\text { dine before starting on } \\
\text { sulfathiazole. }\end{array}$ \\
\hline 20 & $\mathbf{M}$ & 40 & 12 hours & $\mathbf{i}$ & RLL & $\begin{array}{l}22,250 \\
\text { P. } 88 \%\end{array}$ & 105 & May 7 & May 16 & $\begin{array}{ll}\text { May } 10 & 00 \\
\text { May } 13 & 00 \\
\text { May } 15 & 00 \\
\text { May } 17 & ++ \\
\text { May 20 } & ++ \\
\text { May } 23 & ++\end{array}$ & 82 & \\
\hline 21 & $\mathbf{M}$ & 39 & 4 days & $\mathbf{i}$ & RML & $\begin{array}{r}21,280 \\
\text { P. } 88 \%\end{array}$ & 103.4 & May 7 & May 11 & $\begin{array}{lrl}\text { May } & 8 & 00 \\
\text { May } & 13 & 00 \\
\text { May } & 15 & 00 \\
\text { May } & 17 & ++ \\
\text { May } & 23 & ++\end{array}$ & 60 & History of asthma. \\
\hline
\end{tabular}

* First column $=$ two hour reading. Second column $=$ overnight reading.

the time of appearance was accurately determined and its relationship to the beginning of normal temperature known, it may be said that in six the antibody appeared so close to the moment of " essential recovery" as to indicate that it might be playing an important rôle in that process. In six other cases, however, the antibody was not detected until about a week after the temperature had been normal, and in one case not until three weeks had elapsed.

\section{DISCUSSION}

It seems to us that the importance of these observations lies in the fact that a sharp difference is established between the response of patients treated with sulfathiazole and those treated with sulfapyridine when exactly the same technique of investigation is employed in both series. This difference may be expressed as follows: about three-quarters of the cases of lobar pneumonia treated with sulfapyridine recover without the ap- 
pearance of an excess of type-specific antibody in the blood serum as expressed by the precipitin reaction; whereas three quarters of those treated with sulfathiazole do show an excess of antibody. Moreover, when antibody does appear in the sulfapyridine-treated cases, it does so about a week after the temperature has become normal; whereas in about half of the sulfathiazoletreated cases it is first detected near the moment of " essential recovery."

In order to be certain that the facts are as stated, it is necessary to assure oneself that the two series of cases treated were similar. If, for example, one series had contained more very severe cases, or more cases in which treatment was begun late, or fewer examples of the higher types, such a series might be expected to show a higher percentage of antibody-formers. Such was not true of our sulfathiazole-treated group; there were no bacteremic cases, as opposed to two in the sulfapyridine group (both of which showed antibody, one being reported in the original paper). Treatment was actually begun, on the average, one day earlier in the sulfathiazole series than in the sulfapyridine. Lastly, the distribution of types was approximately the same. We therefore feel justified in concluding that a real difference exists between the responses of patients treated with the two drugs.

What is the most likely explanation of this phenomenon? It is theoretically possible that sulfapyridine per se might inhibit antibodyproduction to some degree. We have investigated this hypothesis fairly extensively during the past year by studying the antibody response in laboratory animals which were receiving chemotherapy. Heat-killed pneumococci and egg albumen have been used as antigens and, while the results are somewhat irregular, it is safe to say that neither drug can be shown to inhibit antibodyproduction. The other explanation, and to us the more probable, is that sulfapyridine is a somewhat more powerful antibacterial agent in human lobar pneumonia than is sulfathiazole, and that this difference expresses itself quantitatively in the pro- portion of patients who show a greater activity of their immune mechanisms when treated with the newer drug. Additional support is lent to this hypothesis by the fact that the sulfapyridinetreated cases averaged 1.7 days of fever after treatment was begun, while those on sulfathiazole averaged 3.2 days.

\section{SUMMARY AND CONCLUSIONS}

1. Twenty-one cases of lobar pneumonia treated with sulfathiazole were studied for the appearance of an excess of type-specific antibody in the blood serum by means of the precipitin reaction with specific polysaccharide. Sixteen of these were observed to show an excess of antibody at the time the temperature became normal or thereafter.

2. As we had previously observed that about three-quarters of the patients treated with sulfapyridine did not show antibody, there appears to exist a greater stimulation of this immune mechanism in patients treated with sulfathiazole than in those treated with sulfapyridine.

3. This is interpreted as indicating that sulfapyridine is a somewhat more powerful antipneumococcal agent than sulfathiazole.

\section{BIBLIOGRAPHY}

1. Kneeland, Y., Jr., and Mulliken, B., Antibody formation in cases of lobar pneumonia treated with sulfapyridine. J. Clin. Invest., 1940, 19, 307.

2. Wood, W. B., Jr., and Long, P. H., Observations upon the experimental and clinical use of sulfapyridine. III. The mechanism of recovery from pneumococcal pneumonia in patients treated with sulfapyridine. Ann. Int. Med., 1939, 13, 612.

3. Finland, M., Spring, W. C., Jr., and Lowell, F. C., Immunologic studies on patients with pneumococcic pneumonia treated with sulfapyridine. J. Clin. Invest., 1940, 19, 179.

4. Heidelberger, M., and Kendall, F. E., A quantitative study of the precipitin reaction between type iii pneumococcus polysaccharide and purified homologous antibody. J. Exper. Med., 1929, 50, 809.

5. Tillett, W. S., and Francis, T., Jr., Cutaneous reactions to the polysaccharides and proteins of pneumococcus in lobar pneumonia. J. Exper. Med., $1929,50,687$. 